\title{
Adaptive management: where are we now?
}

\author{
LUCY RIST ${ }^{1 *}$, BRUCE M. CAMPBELL ${ }^{2}$ AND PETER FROST ${ }^{3}$ \\ ${ }^{1}$ Department of Ecology and Environmental Science, Umeå University, 90187 Umea, Smeden, ${ }^{2}$ International Center for Tropical Agriculture \\ (CIAT), clo Department of Agriculture and Ecology, University of Copenhagen, Denmark, and ${ }^{3}$ Science Support Service, 87 Ikitara Road, \\ Wanganui 4500, Nem Zealand
}

Date submitted: 2 December 2011; Date accepted: 17 May 2012; First published online: 16 August 2012

\section{SUMMARY}

Adaptive management (AM) emerged in the literature in the mid-1970s in response both to a realization of the extent of uncertainty involved in management, and a frustration with attempts to use modelling to integrate knowledge and make predictions. The term has since become increasingly widely used in scientific articles, policy documents and management plans, but both understanding and application of the concept is mixed. This paper reviews recent literature from conservation and natural resource management journals to assess diversity in how the term is used, highlight ambiguities and consider how the concept might be further assessed. AM is currently being used to describe many different management contexts, scales and locations. Few authors define the term explicitly or describe how it offers a means to improve management outcomes in their specific management context. Many do not adhere to the idea as it was originally conceived, despite citing seminal work. Significant confusion exists over the distinction between active and passive approaches. Over half of the studies reporting to implement AM claimed to have done so successfully, yet none quantified specific benefits, or costs, in relation to possible alternatives. Similarly those studies reporting to assess the approach did so only in relation to specific models and their parameterizations; none assessed the benefits or costs of AM in the field. AM is regarded by some as an effective and wellestablished framework to support the management of natural resources, yet by others as a concept difficult to realize and fraught with implementation challenges; neither of these observations is wholly accurate. From a scientific and technical perspective many practical questions remain; in particular realworld assessments of the value of experimentation within a management framework, as well as of identified challenges and pathologies, are needed. Further discussion and systematic assessment of the approach is required, together with greater attention to its definition and description, enabling the assessment of new approaches to managing uncertainty, and AM itself.

*Correspondence: Dr Lucy Rist e-mail: lucy.rist@emg.umu.se
Keymords: adaptive management, conservation, decision making, experimental management, natural resource management, uncertainty

\section{INTRODUCTION}

Adaptive management (AM) is natural resource management conducted in a manner that purposely and explicitly increases knowledge and reduces uncertainty (Holling 1978; Walters 1986). Developed by C.S. Holling and Carl Walters, and originally termed adaptive environmental assessment and management, AM emerged in the literature in the mid-1970s in response both to a realization of the extent of uncertainty involved in management (Holling 1978; Walters \& Hilborn 1978), and a frustration with attempts to use modelling to integrate knowledge and make predictions (Walters 2007). Holling and Walters' concept directly linked experimentation in management with a formal process of hypothesis testing and assessment of system response. It also provided a role for wider stakeholder participation, reversing the traditional approach to management based on centralized planning, topdown decision-making and control, with its many limitations (including the exclusion of other interests), and often adverse ecological outcomes (Holling \& Meffe 1996).

Numerous resource management agencies, multinational non-governmental organizations (NGOs) and international policy bodies embraced the idea (Williams \& Johnson 1995; USEPA [United States Environmental Protection Agency] 2000, 2007; Salafsky et al. 2001; CBD [Convention on Biological Diversity] 2004; Linkov et al. 2006; CMP [Conservation Measures Partnership] 2007; Nature Conservancy 2007; WWF [World Wildlife Fund] 2007). AM is firmly established in natural resource management agency practice in the USA at all levels, even without much statutory, regulatory or judicial mandate (Ruhl 2008). Many smaller projects and initiatives followed this trend (for example McCarthy \& Possingham 2007), and the approach is widely cited in the academic literature as an aspiration for natural resource management (Johnson 1999). Indeed, AM has become 'something of a mantra among conservation ecologists and natural resource managers' (Karkkainen 2003) being included as one of the normative concepts in conservation (Callicott et al. 1999) With the surge of interest in AM, the concept has become increasingly commonly simplified, misrepresented or misunderstood (Parma et al. 1998). Efforts 
have been made to clarify the core principles as originally stated, including a distinction made between active and passive AM (see for example Schreiber et al. 2004). Active AM (AAM) is described as management where options are viewed as hypotheses to be tested; experimentation is key and both formalized learning and management are objectives. In contrast, passive AM (PAM) implements a single preferred course of action based on the best available modelling and planning, which is then modified as experience grows (Bryan et al. 2009; Owens 2009; Benson \& Garmestani 2011).

Despite such efforts, significant misunderstanding and ambiguity persists. In many cases, AM is described as representing simply management 'that incorporates past experience' (Varley \& Boyce 2006) or 'learning by doing' (Feldman 2008). Indeed, managers who use a trial-anderror approach to contend with changing resource systems argue that they are already using AM. These misperceptions confound an understanding of what AM requires, how it has been implemented to date, with what accomplishments, and with what future potential (Jacobson et al. 2009; Allen et al. 2011). For example, two divergent perceptions about the use of AM exist in the literature. Some claim AM is a well-developed approach with a wide body of implementation experience, namely '...a well-established concept that has received significant theoretical attention' (Eberhard et al. 2009), and 'a concept that has been increasingly adopted in natural resource management' (Mackenzie \& Keith 2009). Others argue that examples of actual implementation are rare and instances of success even rarer, namely '. . . few successful practical applications of the adaptive management framework' (Bryan et al. 2009), and 'documented failure rates are high' (Eberhard et al. 2009).

In an attempt to highlight and resolve some of this ambiguity, we review the use of the term AM and the approach that it signifies in recently published natural resource management and conservation literature. We document the broad geographical locations, systems, and management contexts in which AM has been discussed or implemented; the components of AM that have been applied; and, where information permits, with what outcomes. Specifically we ask: how is the term AM being used? Does its use vary among published articles and what are the particular points of divergence? To what extent has the practice of AM developed in recent years? Finally, what lessons have been learnt from its application and what challenges remain in applying AM successfully?

\section{METHODS}

A search of ISI Web of Knowledge for 2009 generated 295 records that contained the words 'adaptive management' in their text, title, abstract or keywords. We chose 2009 as this was the most recent full year available to us when starting the study; time did not permit a multi-year review. Papers from 2008 (123 articles) were reviewed initially to test the protocol, following revisions the review was extended to 2009 .
For the sake of consistency, only the 2009 data are analysed here. Nevertheless, the patterns observed in the smaller 2008 set were similar to those of 2009 , giving us confidence that our results reflect a broader pattern. Symposia introductions, response articles (which did not address the AM aspects of the original article) and foreign language publications were excluded. Once duplicate records and papers unrelated to natural resource management were removed, we were left with 187 papers. These were reviewed in two groups: those that discussed AM generally, and those that reported its application.

For both sets of papers we recorded the geographical location of the study, the natural resource of interest, and the scope or scale of management (both from an ecological perspective and from the standpoint of the stated management objectives). The broad management context of the study was also recorded, for example addressing climate change or managing invasive species. Where authors defined AM this was recorded, along with citations of seminal articles or more recently published work. Whereas papers typically cited AM references throughout, we focused only on those citations given in support of a definition of AM. We considered seminal articles to be: Holling (1978); Walters and Hilborn (1978); Walters (1986); Walters and Holling (1990); Lee (1993); Hilborn et al. (1995); Holling (1996); and Holling and Meffe (1996). Although other important papers have been published subsequently, these seven encompass Holling's and Walters' original ideas and the early studies that developed the concept further. Finally, we noted the context in which AM featured: for example, whether a paper advocated AM for tackling a specific management problem or where it made more passing reference to the approach.

AM, as originally stated, has both a formal definition (Walters \& Hilborn 1978; Walters 1986; Walters \& Holling 1990) and specific requirements for application. As such, in the application papers, we assessed if the study adhered closely to the original concept, as reflected in our understanding of its key components based on elements outlined in Walters (1986, p. 9) and Holling (1978, p. 20):

(1) Participation of those outside the management institution in order to manage conflict and increase the pool of contributions to potential management solutions,

(2) Defining and bounding of the management problem, including the setting of management objectives,

(3) Representing existing understanding through system models that include assumptions and predictions as a basis for further learning,

(4) Identifying uncertainty and alternate hypotheses based on experience,

(5) Implementation of actions/policies to allow continued resource management or production while learning (reducing uncertainty),

(6) Monitoring of the effect of implementing new policies,

(7) Reflection on, and learning from, monitoring results, comparison with original expectation in order to revise 
models and/or management actions based on what has been learned, and

(8) Iterative repetition of this cycle (points 1-6 above) so that management reduces uncertainties and leads to improved management outcomes over time.

We assessed which of these was most commonly acknowledged or, conversely, omitted. The assessment was based only on explicit description of a completed activity, or of one planned but not yet implemented, within the paper, nevertheless this provided insights into the use of the concept.

\section{DEFINITIONS AND APPLICATIONS}

Of the 187 papers assessed, 56\% advocated the use of AM. Most of these only briefly referred to AM, highlighting it as the preferred approach to management. None assessed its feasibility in the given context, nor did any explore other 'nonadaptive' options. Another 29\% included AM in the abstract, conclusion or keywords with no elaboration in the paper or a clear link to the main research presented. Indeed, one paper contained 'adaptive management' in the title but without subsequent reference to the concept. Seven per cent critiqued $\mathrm{AM}$ in some way, either in theory or in its application. Only $8 \%$ (15 papers) actually reported having implemented AM.

Only $18 \%$ of papers defined AM. Three gave their own definitions; the rest (31 papers) paraphrased or cited existing definitions. Many of these were rather brief and did not make specific reference to stages or components of the process but rather focused on its underlying premise or ideology. Eleven quoted one or more of the seminal articles, 13 cited seminal articles along with new work, and seven only cited recent work. These recent works included reports from the Canadian Forest Service and The British Columbia Ministry of Forests (Canadian Forest Service 2011; Nyberg 1998) as well as discipline-specific journal articles (Kay \& Alder 2005), articles reporting on the application of AM (Nichols 2000) and those assessing its usefulness (Wilhere 2002).

In looking at the geographic location in focus in the papers, the largest proportion notably related to North American systems, where AM was originally developed; Australia also featured prominently (Fig. 1). In contrast, Asia, South America and Africa were represented by only a small number of studies (Fig. 1). Nearly half the papers focused on terrestrial systems, more than twice the amount that considered marine systems (Fig. 1).Water and biodiversity were the two largest natural resource categories, each accounting for $>20 \%$ of papers. Fisheries, the focus of much early discussion of AM, accounted for only $7 \%$ of studies (Fig. 1). Studies with a landscape scope were most common, single species studies the least (Fig. 1). Studies where management focused on achieving a specific, usually narrow, conservation objective, or for the supply of a particular resource, were more common than integrated or multi-objective management objectives (Fig. 1). Although 24\% of papers addressed contexts where the management problem encompassed multiple challenges, the broad context for most studies was the management process itself (for example data sharing or management appraisal), followed by climate change and sustainable use (Fig. 1).

A distinction between 'active' and 'passive' AM featured in several of the papers, yet was inconsistent among them (Table 1). Active AM was framed by some as a process in which different management actions designed to achieve a specified goal are tested simultaneously, akin to experimental treatments (see Bryan et al. 2009; Dzus et al. 2009). Most did not specify the need to test a range of options simultaneously, but focused on learning as an explicit objective of management being the key differentiating feature (for example Bond \& Loomis 2009; Lawler 2009; Owens 2009). Others highlighted quantitative system modelling as the distinguishing feature of AAM (Jacobson et al. 2009). Wilson et al. (2009) suggested three options: passive, active and experimental AM, but their definitions for active and experimental AM both focus on deliberate learning and are not clearly distinguishable (that is, they contrast 'manage optimally for learning' with 'manipulation of the system to maximize the speed of learning'; see Table 1).

\section{APPLICATION OF ADAPTIVE MANAGEMENT}

Taking those 15 papers which reported having applied AM, how does the management described in each correspond to the AM framework (see list of AM components in methods)? On average each paper included less than five of the eight components. Those most commonly omitted were participation and iteration of the management cycle (Table 2). In some cases this was a consequence of management still being in the assessment and planning phase; for others one cycle was completed but no indication given of the intention for an iterative process. Of the 15 , assuming benefits can be obtained before completing a full management cycle, nine studies reported using AM successfully, one reported implementation as a failure (Norgaard et al. 2009) and five provided no statement on the outcome.

Of those reporting success, this was either in terms of enhanced stakeholder involvement (Bryan et al. 2009), progress towards achieving management objectives (Bryan et al. 2009; Eberhard et al. 2009; Mackenzie \& Keith 2009), or informative assessment and monitoring (Ascoli et al. 2009; Blackstock 2009; Bryan et al. 2009; Castley et al. 2009; Densmore \& Karle 2009; Melzer et al. 2009; Newlin \& Johnson 2009). Five studies had more than one objective in management, and five focused on management at a landscape scale. None included an assessment of success in relation to possible 'non-AM' alternatives. Several noted challenges to implementation (Table 3). We identified four categories 
Figure 1 Characteristics of reviewed studies. Outer circles represent the full number of reviewed papers (a total of 187 papers), inner circles the subset of implementation papers (a total of 15 papers). NA $=$ not applicable.
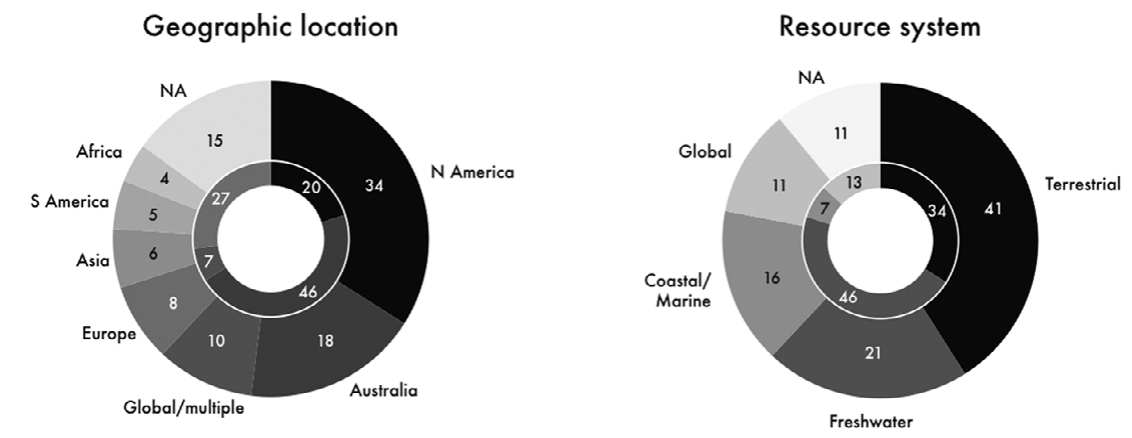

Natural resource of interest
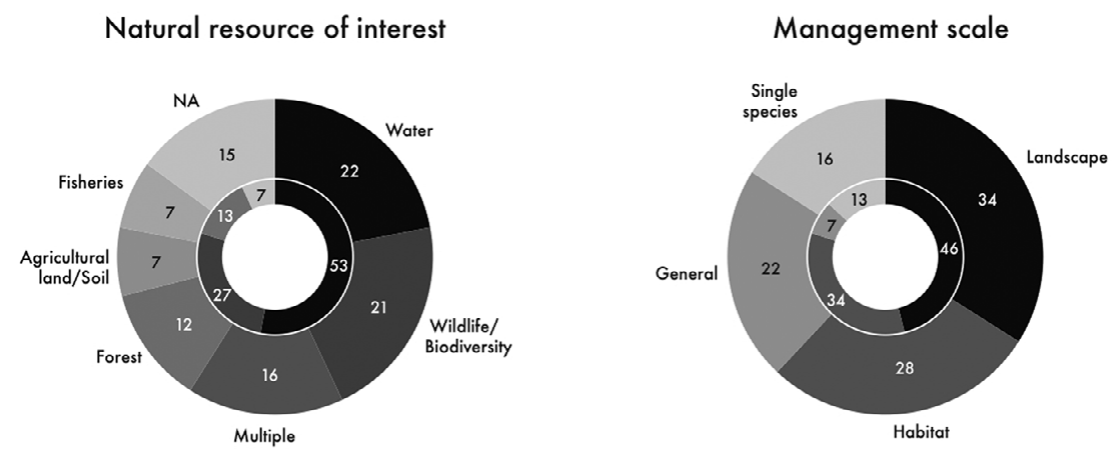

Management objective

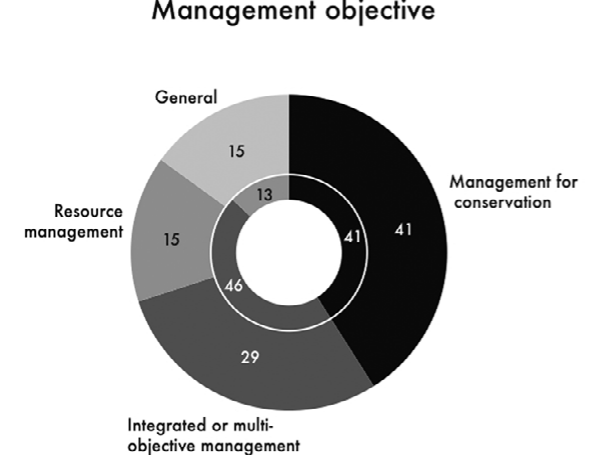

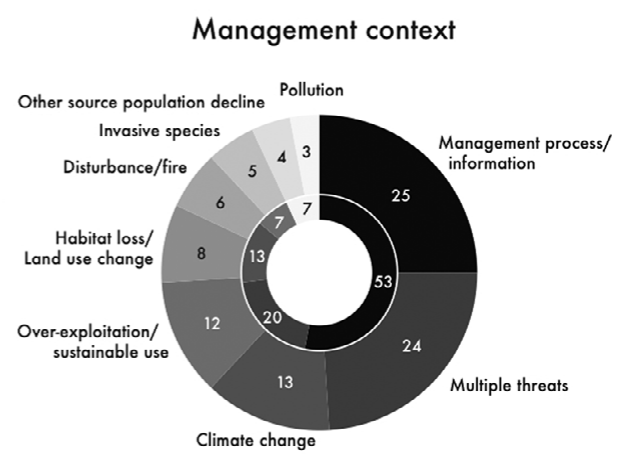

of constraints amongst the studies (there may however be others that did not feature in the studies we reviewed): (1) logistical, financial and staffing constraints; (2) the need for a supportive institutional environment; (3) challenges relating to experimentation within a management framework; and (4) problems relating to spatial and temporal scale (Table 3). For example, Norgaard et al. (2009) highlighted the difficulties of identifying indicators to assess the state and trajectory of the system in the face of other drivers of change in addition to management interventions, often acting at larger scales. Which of these is specific to AM, as opposed to management generally, was, however, not always clear.

\section{APPRAISING ADAPTIVE MANAGEMENT}

In addition to papers describing applications of AM, 13 studies appraised the benefits and drawbacks of AM, including instances of premature assessment (Simberloff 2009), benefits in relation to the integration of ecological research within management decision-making (Gosselin 2009), collaborative governance (Kallis et al. 2009; Sagoff 2009), dealing with complex problems and uncertainty (Boyd \& Svejar 2009; Prato $2009 a, b, c)$, evaluations of its utility through modelling (Bond \& Loomis 2009; Martin et al. 2009, Rout et al. 2009), and discussion of separate discourses (Jacobson et al. 2009; Owens 2009). None assessed the benefits or costs of AM in the field, including in relation to possible alternatives.

Several modelling studies showed the benefits of deliberate learning, but only in relation to specific models and their parameterizations. Bond and Loomis (2009) used numerical dynamic programming to estimate when to experiment, and by how much, thereby determining the trade-off between meeting short-term management goals and longerterm learning to improve management. They found a small 
Table 1 Descriptions of active and passive adaptive management (quotations taken directly from reviewed articles).

\begin{tabular}{|c|c|c|}
\hline Author & Passive & Active \\
\hline Baron et al. (2009) & $\begin{array}{l}\text { Relies on historical information to construct } \\
\text { a conceptual model of how a system works } \\
\text { and how it will respond to changing } \\
\text { conditions }\end{array}$ & $\begin{array}{l}\text { Involves direct manipulation of key ecological } \\
\text { processes to test understanding of } \\
\text { relationships among system components } \\
\text { and drivers and to examine the effects of } \\
\text { policies or decisions }\end{array}$ \\
\hline Bond and Loomis (2009) & Learning is not anticipated & Learning is anticipated \\
\hline Brown (2009) & $\begin{array}{l}\text { Places a greater emphasis on adjusting } \\
\text { models used as the basis for } \\
\text { decision-making }\end{array}$ & $\begin{array}{l}\text { Emphasizes monitoring in an experimental } \\
\text { context, extending all the way to a } \\
\text { 'management by hypothesis' approach }\end{array}$ \\
\hline Bryan et al. (2009) & $\begin{array}{l}\text { Implements a single preferred course of } \\
\text { action based on the best available } \\
\text { modelling and planning }\end{array}$ & $\begin{array}{l}\text { Implements a range of competing alternative } \\
\text { courses of action framed as formal } \\
\text { experimental treatments subject to rigorous } \\
\text { (often statistical) evaluation }\end{array}$ \\
\hline Dzus et al. (2009) & 'Trial and error' & $\begin{array}{l}\text { A systematic process of modelling, } \\
\text { experimentation and monitoring to } \\
\text { compare the outcomes of alternative } \\
\text { management actions, tests alternative } \\
\text { practices simultaneously as opposed to } \\
\text { sequentially }\end{array}$ \\
\hline Gosselin (2009) & Not given & $\begin{array}{l}\text { A form of adaptive management based on } \\
\text { experimentation }\end{array}$ \\
\hline Jacobson et al. (2009) & $\begin{array}{l}\text { Involves adapting management decisions, } \\
\text { using the monitoring of management } \\
\text { actions to improve outcomes and to ensure } \\
\text { management decision-making and policy } \\
\text { implementation are more defensible }\end{array}$ & $\begin{array}{l}\text { Projects that build a quantitative system } \\
\text { model to make predictions about the } \\
\text { outcomes of management actions. In such } \\
\text { cases, policies act as hypotheses and } \\
\text { management as an experiment to be } \\
\text { implemented scientifically }\end{array}$ \\
\hline Lawler (2009) & $\begin{array}{l}\text { Involves building a management strategy } \\
\text { based on historic data and then altering } \\
\text { that strategy with new data as the system is } \\
\text { monitored over time }\end{array}$ & $\begin{array}{l}\text { Involves conscious experimentation, } \\
\text { generally exploring the outcomes of } \\
\text { multiple management strategies }\end{array}$ \\
\hline Martin et al. (2009) & $\begin{array}{l}\text { Learning about the system behaviour occurs, } \\
\text { but as a by-product of management }\end{array}$ & $\begin{array}{l}\text { Is a formal attempt to deal with the so-called } \\
\text { dual control problem of simultaneously } \\
\text { meeting short-term system objectives and } \\
\text { learning in order to make even better } \\
\text { decisions in the future }\end{array}$ \\
\hline Maxted (2009) & Not given & $\begin{array}{l}\text { Existing knowledge is used to design } \\
\text { experiments that test hypotheses about } \\
\text { ecosystem responses to management }\end{array}$ \\
\hline Owens (2009) & $\begin{array}{l}\text { Managers implement the alternative they } \\
\text { think is 'best' (with respect to meeting } \\
\text { management objectives), and then monitor } \\
\text { to see if they were correct, making } \\
\text { adjustments if desired objectives are not } \\
\text { met }\end{array}$ & $\begin{array}{l}\text { Managers implement more than one } \\
\text { alternative as concurrent experiments to } \\
\text { see which will best meet management } \\
\text { objectives }\end{array}$ \\
\hline Prato $(2009 c)$ & $\begin{array}{l}\text { Management team selects and implements } \\
\text { the best compensatory management action } \\
\text { for reducing the adverse impacts of future } \\
\text { climate change and variability before that } \\
\text { change occurs }\end{array}$ & $\begin{array}{l}\text { Management team adjusts compensatory } \\
\text { management actions over time, as needed, } \\
\text { based on the results of testing hypotheses } \\
\text { about the efficacy of those actions in } \\
\text { alleviating adverse species impacts... treats } \\
\text { management actions as experiments that } \\
\text { generate information for testing hypotheses } \\
\text { about ecosystem responses }\end{array}$ \\
\hline Prober and Smith (2009) & Not given & $\begin{array}{l}\text { Decisions are informed by general ecological } \\
\text { theory or existing knowledge, and these are } \\
\text { increasingly refined for local ecosystems } \\
\text { through strategic evaluation }\end{array}$ \\
\hline
\end{tabular}


Table 1 continued

\begin{tabular}{|c|c|c|}
\hline Author & Passive & Active \\
\hline Rout et al. (2009) & $\begin{array}{l}\text { Learning is valued, but is not part of the } \\
\text { management plan }\end{array}$ & $\begin{array}{l}\text { The ability to learn influences management } \\
\text { decisions: there is a balance between } \\
\text { achieving the objective in the present and } \\
\text { learning for improved management in the } \\
\text { future }\end{array}$ \\
\hline Wasserburg et al. (2009) & Not given & $\begin{array}{l}\text { Involves generation of alternative hypotheses } \\
\text { and specific management experiments to } \\
\text { evaluate these hypotheses }\end{array}$ \\
\hline Wilson et al. (2009) & $\begin{array}{l}\text { Learn by analysing the outcomes of past } \\
\text { interventions }\end{array}$ & $\begin{array}{l}\text { Optimally manage taking into account the } \\
\text { possibility for learning. }{ }^{*} \text { Wilson also } \\
\text { outlined experimental adaptive } \\
\text { management (actively manipulate the } \\
\text { system to maximize learning speed) }\end{array}$ \\
\hline
\end{tabular}

Table 2 Components of an AM approach included in implementation papers. Components are listed in procedural order; participation occurs throughout the process and hence is listed first.

\begin{tabular}{lc}
\hline \hline Adaptive management component & Number of papers \\
\hline 1. Participation of those outside the management institution in order to manage conflict and increase the & 8 \\
pool of contributions to potential management solutions & 9 \\
2. Defining and bounding of the management problem, including the setting of management objectives & 8 \\
3. Representing existing understanding through system models that include assumptions and predictions as & \\
a basis for further learning & 8 \\
4. Identifying uncertainty and alternate hypotheses based on experience & 7 \\
5. Implementation of actions/policies to allow continued resource management or production while & 12 \\
learning (reducing uncertainty) & 13 \\
6. Monitoring of the effect of implementing new policies & 8 \\
7. Reflection on, and learning from, monitoring results, comparison with original expectation in order to \\
revise models and/or management actions based on what has been learned \\
8. Iterative repetition of this cycle (points 1-6 above) so that management reduces uncertainties and lead to \\
improved management outcomes over time
\end{tabular}

benefit of active over passive learning, but how much to experiment depended critically on the level of uncertainty in the system and on the managers' conception of this. Rout et al. (2009) also assessed the optimal balance between shortterm management objectives and the longer-term benefits of learning. When uncertainty was high and there was time to benefit from new knowledge, the potential advantages to management (of an active approach) were significant. This was a simulation study, however, so actual success (or failure) could not be assessed. While these results are likely to be specific to the model and the parameters used, these studies illustrate two points. First, the actual benefit gained by experimentation depends on the true underlying ecosystem parameters about which there is uncertainty. For example, if management is concerned about crossing a threshold that would lead to undesirable consequences and there is uncertainty about this threshold, if the true value of the threshold is low, then despite expected benefits from experimentation passive learning can perform equally well. Second, they highlight the key role of the decisionmakers' inherently subjective beliefs in shaping values towards experimentation.

\section{DISCUSSION}

\section{Definitions of adaptive management}

Much ambiguity still surrounds AM. The term has been used to describe anything from formal natural resource management or conservation experiments (see for example Ascoli et al. 2009), to modelling management options (see Newlin \& Johnson 2009), or encouraging participation and social learning (see Levrel et al. 2009). Some variation is to be expected, either when a concept is defined in a specific context, or when elaborating it to accommodate new circumstances or particular needs as, for example, in concepts of adaptive comanagement or adaptive collaborative management (Pierce Colfer et al. 2005). Different interpretations also reflect the diverse array of natural resources and management circumstances. Nevertheless, AM has both a formal definition and specific operational requirements. If used loosely, the concept risks being weakened, its core ideas obscured and its utility limited. Applying a concept effectively, including in environmental management, depends both on explicit definition of its core elements and on clearly framing that meaning in a given case (Pickett et al. 1994). Apart 
Table 3 Studies providing examples of AM implementation ( ${ }^{*}$ modelling studies not field implementation).

\begin{tabular}{|c|c|c|c|c|c|c|c|c|c|}
\hline Study & $\begin{array}{c}\text { Resource management } \\
\text { problem }\end{array}$ & $\begin{array}{l}\text { Management } \\
\text { scale }\end{array}$ & $\begin{array}{l}\text { Multiple } \\
\text { objectives }\end{array}$ & $\begin{array}{l}\text { Previous } \\
\text { field data } \\
\text { available }\end{array}$ & $\begin{array}{l}\text { Hypotheses } \\
\text { stated }\end{array}$ & $\begin{array}{l}\text { Contrasting } \\
\text { management } \\
\text { regimes (i.e. } \\
\text { experimental } \\
\text { replication) }\end{array}$ & $\begin{array}{l}\text { Does man- } \\
\text { agement } \\
\text { deal mill } \\
\text { competing } \\
\text { demands? }\end{array}$ & $\begin{array}{c}\text { Time scale of } \\
\text { implementation } \\
\text { (Number of cycles } \\
\text { completed) }\end{array}$ & $\begin{array}{c}\text { Identified constraints } \\
\text { (category of } \\
\text { constraint) }\end{array}$ \\
\hline Ascoli et al. (2009) & $\begin{array}{l}\text { Wildlife/biodiversity: } \\
\text { identification of } \\
\text { prescribed burning } \\
\text { regime for Calluna } \\
\text { heathlands }\end{array}$ & Habitat & No & $\begin{array}{l}\text { Only more } \\
\text { general } \\
\text { data } \\
\text { available }\end{array}$ & Yes & Yes & No & $\begin{array}{l}4 \text { years (1 cycle } \\
\text { complete), } \\
\text { commencing } \\
\text { second cycle }\end{array}$ & $\begin{array}{l}\text { Logistical and } \\
\text { resource constraints } \\
\text { (1) }\end{array}$ \\
\hline $\begin{array}{l}\text { Blackstock et al. } \\
(2009)\end{array}$ & $\begin{array}{l}\text { Water: river basin } \\
\text { management } \\
\text { planning in the } \\
\text { context of climate } \\
\text { change }\end{array}$ & Landscape & Yes & Little & Not given & No & Yes & $\begin{array}{l}3 \text { years, still in } \\
\text { planning/ } \\
\text { assessment phase }\end{array}$ & $\begin{array}{l}\text { Conflicts with formal } \\
\text { regulations (2) }\end{array}$ \\
\hline Blackstock (2009) & $\begin{array}{l}\text { Water: river basin } \\
\text { management } \\
\text { planning }\end{array}$ & Landscape & Yes & Little & Not given & $\begin{array}{l}\text { No (passive } \\
\text { view of AM) }\end{array}$ & Yes & $\begin{array}{l}1 \text { year, }(1 \text { cycle } \\
\text { complete), } \\
\text { commencing } \\
\text { second cycle }\end{array}$ & $\begin{array}{l}\text { Reconciling long and } \\
\text { short term } \\
\text { management } \\
\text { priorities (4) }\end{array}$ \\
\hline Bryan et al. (2009)* & $\begin{array}{l}\text { Water: mitigating } \\
\text { Cryptosporidium } \\
\text { risk in water sources }\end{array}$ & Landscape & Yes & Yes & Yes & No & Yes & $\begin{array}{l}\text { Not given (1 cycle), } \\
\text { planning second } \\
\text { cycle }\end{array}$ & $\begin{array}{l}\text { Limited learning due } \\
\text { to passive approach } \\
\text { (3) }\end{array}$ \\
\hline Castley et al. (2009) & $\begin{array}{l}\text { Wildlife/biodiversity: } \\
\text { managing tourism } \\
\text { and biodiversity in } \\
\text { protected areas }\end{array}$ & Landscape & Yes & Yes & Not given & No & Yes & Not given & Not given \\
\hline $\begin{array}{l}\text { Densmore and } \\
\text { Karle (2009) }\end{array}$ & $\begin{array}{l}\text { Water: mitigating } \\
\text { impacts of floods } \\
\text { with respect to } \\
\text { stream restoration }\end{array}$ & Landscape & Yes & No & Yes & Yes & No & $\begin{array}{l}15 \text { years (one cycle) } \\
\text { surveys done } \\
\text { every } 1 \text { to } 3 \text { years }\end{array}$ & Not given \\
\hline $\begin{array}{l}\text { Eberhard et al. } \\
(2009)\end{array}$ & $\begin{array}{l}\text { Water: watershed } \\
\text { catchment } \\
\text { management for } \\
\text { improved water } \\
\text { quality }\end{array}$ & Landscape & No & Not given & Not given & Not given & Yes & $\begin{array}{l}5 \text { years, further } \\
\text { details not given }\end{array}$ & $\begin{array}{l}\text { Lag times and } \\
\text { variability conflict } \\
\text { with management } \\
\text { timescale (4) }\end{array}$ \\
\hline $\begin{array}{l}\text { Mackenzie and } \\
\text { Keith (2009) }\end{array}$ & $\begin{array}{l}\text { Forest: reduce } \\
\text { extinction risk of a } \\
\text { threatened tree } \\
\text { population }\end{array}$ & Single species & No & Yes & Yes & Yes & No & $\begin{array}{l}4 \text { years ( } 1 \text { cycle } \\
\text { completed, } \\
\text { monitoring for } \\
\text { second on-going) }\end{array}$ & Not given \\
\hline Melzer et al. (2009) & $\begin{array}{l}\text { Wildlife/biodiversity: } \\
\text { pest management }\end{array}$ & Habitat & No & Yes & Yes & No & No & $\begin{array}{l}\text { First cycle not } \\
\text { complete }\end{array}$ & $\begin{array}{l}\text { Long time frames } \\
\text { therefore assessing } \\
\text { effectiveness must } \\
\text { occur on } \\
\text { longer-term (4) }\end{array}$ \\
\hline
\end{tabular}




\begin{tabular}{|c|c|c|c|c|c|c|c|c|c|}
\hline Study & $\begin{array}{c}\text { Resource management } \\
\text { problem }\end{array}$ & $\begin{array}{l}\text { Management } \\
\text { scale }\end{array}$ & $\begin{array}{l}\text { Multiple } \\
\text { objectives }\end{array}$ & $\begin{array}{l}\text { Previous } \\
\text { field data } \\
\text { available }\end{array}$ & $\begin{array}{c}\text { Hypotheses } \\
\text { stated }\end{array}$ & $\begin{array}{l}\text { Contrasting } \\
\text { management } \\
\text { regimes (i.e. } \\
\text { experimental } \\
\text { replication) } \\
\end{array}$ & $\begin{array}{l}\text { Does man- } \\
\text { agement } \\
\text { deal mill } \\
\text { competing } \\
\text { demands? }\end{array}$ & $\begin{array}{c}\text { Time scale of } \\
\text { implementation } \\
\text { (Number of cycles } \\
\text { completed) }\end{array}$ & $\begin{array}{c}\text { Identified constraints } \\
\text { (category of } \\
\text { constraint) }\end{array}$ \\
\hline $\begin{array}{l}\text { Newlin \& Johnson } \\
(2009)\end{array}$ & $\begin{array}{l}\text { Water: mitigation } \\
\text { measures for stream } \\
\text { sediment deposition }\end{array}$ & Habitat & Yes & Not given & Yes & Yes & No & 4 cycles & Not given \\
\hline Norgaard (2009) & $\begin{array}{l}\text { Water: management of } \\
\text { the CALFED } \\
\text { Bay-Delta }\end{array}$ & Landscape & Yes & Not given & Not given & No & Yes & 7 years (one cycle) & $\begin{array}{l}\text { System changed } \\
\text { before learning } \\
\text { about dynamics } \\
\text { could take place; } \\
\text { difficulty in } \\
\text { establishing reliable } \\
\text { indicators/metrics } \\
\text { for state of the } \\
\text { system; } \\
\text { management } \\
\text { implemented at } \\
\text { small scales but } \\
\text { changes taking } \\
\text { place at larger } \\
\text { spatial and } \\
\text { temporal scales } \\
\text { which eroded } \\
\text { progress (4) }\end{array}$ \\
\hline $\begin{array}{l}\text { O'Toole et al. } \\
(2009)\end{array}$ & $\begin{array}{l}\text { Water: information } \\
\text { exchange in } \\
\text { regional-scale water } \\
\text { management }\end{array}$ & Landscape & No & Yes & Not given & No & Yes & Not given & $\begin{array}{l}\text { Engagement and } \\
\text { communication in } \\
\text { management/ } \\
\text { governance process } \\
\text { (2) }\end{array}$ \\
\hline Parr et al. (2009) & $\begin{array}{l}\text { Wildlife/biodiversity: } \\
\text { assessing } \\
\text { effectiveness of } \\
\text { biodiversity research } \\
\text { and management } \\
\text { practice }\end{array}$ & Multi-species & No & Not given & Not given & Not given & Not given & Not given & Not given \\
\hline $\begin{array}{l}\text { Priddel and Carlile } \\
\text { (2009) }\end{array}$ & $\begin{array}{l}\text { Wildlife/biodiversity: } \\
\text { threatened species } \\
\text { recovery programme }\end{array}$ & Single species & No & Yes & Yes & Yes & No & Not given & Not given \\
\hline Seidl et al. (2009)* & $\begin{array}{l}\text { Forest: consequences } \\
\text { of climate- induced } \\
\text { changes in the biotic } \\
\text { disturbance regime }\end{array}$ & Habitat & No & Yes & Yes & Yes & No & $\begin{array}{l}95 \text { years total, } 5 \\
\text { year simulation } \\
\text { periods (cycles) }\end{array}$ & Not given \\
\hline
\end{tabular}
the CALFED about dynamics difficulty in establishing reliable ors/metrics small scales but ace at large temporal scales which eroded communication in regional-scale water nce regime 
from providing clear direction, this promotes a common understanding of intentions, actions and both anticipated and actual outcomes, which fosters shared learning and promotes progress (Runge 2011). Additionally this would aid more efficient policy formulation and the provision of incentives to overcome barriers to the implementation of AM, including technical challenges (see Moore et al. 2011)

Many who use the term AM rarely define it clearly or specify just how to apply it. Too often it seems to be used as a buzzword: for example, we identified one paper where AM featured in the title but nowhere else in the paper. The ubiquitous use of the term creates the illusion of a large literature, when in reality its practical application and evaluation is not so extensive. Increasing reference to new literature might reflect development of the concept beyond Walters' and Holling's original work, but we found that although several authors cited new work, most simply relied on seminal articles, even while sometimes misstating the core concepts. Greater attention needs to be given to adhering to the definition and description of AM by both the scientific and policy communities so that new ideas can develop, and the original concept evolve (Allen et al. 2011; Runge 2011). More specifically, for management to be considered as AM it must include a formalized process of learning, preferably combined with deliberate experimentation, a core concept of AM (Walters 2007). By formalized learning we refer to comparison with original expectation in order to revise models and/or management actions based on what has been learned, this includes specific articulation of what information is being sought and precisely how it will change future decisions (Runge 2011).

\section{Active and passive adaptive management}

The distinction between passive and active AM is a particular point of confusion. Walters and Holling (1990) emphasized a distinction between 'active' and 'passive' adaption in management. Their article suggested that most management is characterized by passive adaptation to change and they proposed $\mathrm{AM}$ as an alternative to this; rather than specifically presenting passive and active as two alternatives of AM. However, a general characterization of these two as alternative 'versions' of AM is common the literature (see Williams 2011a). For example, McCarthy and Possingham (2007) described PAM as that in which learning occurs serendipitously and is then incorporated into management plans; other authors give similar interpretations (Bond \& Loomis 2009; Martin et al. 2009; Rout et al. 2009; Williams 2011a). To some extent, all managers change what they do in response to continuous learning about and interaction with the system in question. Reflecting on actions typically leads at some point to the revision of management decisions; a manager would normally make use of past experiences when making decisions. Hence, what specifically is novel about 'passive' AM as opposed to 'normal' or 'best practice' management? In many cases PAM is currently being used as a new label for conventional ways of managing. Using monitoring and reflection to improve outcomes and to ensure that management decision-making and policy implementation are more defensible can be considered good practice, but not specifically AM.

Williams $(2011 a)$ considered that it is the use of what is learned to adjust management strategy that distinguishes AM. We argue that, in fact, all management adjusts in response to learning; it is rather the formalization of the learning process, often combined with explicit experimentation in order to aid learning about the structure of the biological and ecological relationships that drive resource or system dynamics that are the defining characteristics of AM. PAM can then be contrasted from AAM as that which retains this formalized learning as a process underlying the adjustment of management decisions but which does not explicitly experiment (Jacobson et al. 2009). For example, The US Fish and Wildlife Service's Adaptive Harvest Management programme, while not involving experimentation as such, incorporates competing models of waterfowl population dynamics and harvest impacts together with model averaging to compute optimal strategies for regulating harvest (Johnson 2011; US Fish \& Wildlife Service 2011). Here, the emphasis is on managing a dynamic system in the face of uncertainty, with reduction of uncertainty not occurring experimentally, but rather through ongoing management adjustments and monitoring of the system.

We suggest that coining of the term 'active AM' was an attempt to refocus on the experimentation element that Walters and Holling's work emphasized (Walters 2007), an observation supported by Allen and Gunderson (2011). While subdivision of the AM concept into passive and active approaches has been useful, we believe that refocusing on deliberate experimentation as articulated by Walters and Hollings may also hold promise for further development of the AM concept. While AM in its entirety is certainly more than this (see list of AM components in Methods), one of its novelties lies in the idea that experimentation is necessary in order to learn about a system, a focus that has been lost (Walters 2007; Walters \& Holling 1990).

\section{The myths and realities of adaptive management}

AM is claimed by some to be a well-developed approach (for example Eberhard et al. 2009). This is not necessarily the case. While the theory of AM is clear (if at times misunderstood or misrepresented), in many respects the approach remains little explored. Few studies presented a framework for a specific management problem or documented an application, and even fewer assessed relative costs and benefits. McFadden et al. (2011) drew similar conclusions in their recent review, finding a comparable small percentage of implementation studies (13\% in MacFadden et al. versus $11 \%$ in this study). Others claim examples of successful application are rare (Allen \& Gunderson 2011); again this is not necessarily the 
case. Although published examples of actual application of AM are certainly uncommon, we found as much evidence of its value (nine out of 15 articles in this review across a diverse set of contexts and management problems) as of its supposed shortcomings. Of course, this depends on what was implemented, and how success is defined, but if reported as having value to management then it is likely that the approach, or at least components of it, have something to offer. Indeed, McFadden et al. (2011), in considering success in AM to be 'a favourable or desired outcome', recognized that there is a range of outcomes that could be considered successful in a given context. Given the varying interpretations of AM, we believe that conclusions about its effectiveness have been premature and further work is needed to evaluate the approach itself and what constitutes success when it is implemented, a need also recently highlighted by McFadden et al. (2011).

There is also some misrepresentation in relation to the commonly-cited barriers to implementing AM. Supporters and critics alike have identified many potential problems, principally ones of cost, institutional barriers, and the capacity and conflicting priorities of stakeholders (McLain \& Lee 1996; Walters 1997; Rogers 1998: Johnson 1999; Lee 1999; Rogers et al. 2000; Moir \& Block 2001; Ladson \& Argent 2002). Yet while these emerged in the critique papers, none figured prominently in the application papers we reviewed. For example, none reported that costs or stakeholder groups had proved to be stumbling blocks. Recently, Allen and Gunderson (2011) identified nine pathologies and challenges for AM, but perhaps just one of these ('experiments are difficult') could be considered to be specific to AM, a point Allen and Gunderson (2011) themselves highlighted when they stated 'the pathologies we identify may be present in other forms of AM, or in any type of resource management, for that matter'.

There is a need to differentiate clearly between where AM failed to deliver management benefits (namely whether another management approach would have been better), as opposed to where the management system itself failed. For example, Sagoff (2009) raised concerns about whether AM could ensure the democratic political process required for making decisions in the context of management of the Kings Bay/Crystal River ecosystem. More specifically, he noted that 'adaptive ecosystem management provides an academic blessing for this kind of 'group grope' - a way to institutionalize paralysis by analysis and to guarantee indecision over the long run' (Sagoff 2009). Such broad statements disparaging all AM overlook the fact that failure to implement AM may be a failure of managers and the systems within which they work rather than that of AM specifically. Cost, institutional barriers and difficulties with stakeholder engagement are not particular to AM and it would be more accurate to discuss these as barriers to effective management in general. While commonly cited as a barrier, to our knowledge no studies have compared the cost of AM with conventional management approaches (i.e. those in which explicit experimentation, or a formalized learning process does not feature) within a particular system. Such analyses would be most useful.

AM continues to be hailed as a panacea, and specifically as a solution for many large-scale management problems (see Johnson 1999; Owens 2009). Indeed AM is often associated with large-scale applications and high complexity (Williams 2011b). However, there have also been suggestions that large complex problems might not be the best context for AM implementation. Implementation at small scales, in simple systems in which existing data suggest the causal relationships, and where contrasting management regimes can be introduced to test the hypothesized relationships might be more applicable (Gregory et al. 2006; Simberloff 2009). For example, AM is frequently discussed as a valuable approach in relation to climate change (24 studies in our review), even though this could be characterized as a problem of intricate complexity, high external influences, long time spans, high structural uncertainty and with low confidence in assessments (Gregory et al. 2006). Until AM is consistently defined and elaborated, it remains to be established in which management contexts it can most appropriately be applied.

Finally, some assume AM to be a valuable tool for climate change adaptation (Ogden \& Innes 2009) and a valuable approach in 'managing for resilience' (for example Anderies et al. 2006; Benson \& Garmestani 2011). The theoretical basis of both these assumptions remains untested. A more inclusive management process may indeed enhance adaptive capacity and resilience to climate change (Tompkins \& Adger 2004), but AM has many other components that may be incompatible with these management perspectives. Some authors also confuse 'management for adaptation' with 'adaptive management', with AM being interpreted as management that adapts to change and has the flexibility to deal with new challenges (Pereira et al. 2009). It may indeed contribute to managing for adaptation but the two concepts are distinct, and AM's potential contribution will depend on the time required to learn and the ability to detect the effects of management against a broader background of change. Long lag times mean that the outcomes of management can only be assessed in the long term; yet with such time scales distinguishing the effects of management from those of other factors may be challenging. Management implemented at small scales, but influenced by a backdrop of change occurring at larger spatial and longer temporal scales, may similarly lead to changes in the system occurring before learning about dynamics can take place (Norgaard et al. 2009; Tyre et al. 2011). Moreover, AM includes an assumption of dynamic stability in the underlying environment and the structural features of the resource system (Williams 2011b). Directional change in the environment (for example long-term decreases in average rainfall or increases in the range of ambient temperatures) is now often a feature of resource management decision making. This may be a significant challenge for AM's approach to decision making 
in the context of climate change (Norgaard et al. 2009; Williams 2011b).

\section{CONCLUSIONS}

$\mathrm{AM}$ has become a prominent concept in natural resource management and yet in reality is still a relatively undeveloped area of research. Many have commented that the major challenges facing AM are fundamentally institutional rather than technical (see Stankey et al. 2005). Yet while management's greatest challenges may indeed be institutional, few of these are specific to AM. From a scientific and technical perspective many practical questions specific to AM remain.

Modelling shows that management tends to be precautionary in the short- to medium-term, rather than experimental (Hauser \& Possingham 2008; Moore 2008); in essence, actions with known moderate benefits are preferred over actions with uncertain but marginally larger expected benefits. By itself, however, modelling cannot be a test of AM. Real-world assessments of the value of experimentation within a management framework are needed, specifically reconciling long- and short-term management priorities and the perceived risk of experimentation with the potential for long-term management benefit.

Proper evaluation of other identified pathologies and challenges are also needed. Logistical, financial and staffing constraints have been identified. To what extent AM places greater demands in these respects, and what specific tradeoffs with management 'success' might be involved, are also uncertainties and are likely to be highly context specific. Spatial and temporal scale (for example lag times, inherent variability and cross-scale interactions) and the difficulty in establishing reliable indicators and experiments that result in strong inference are perhaps the biggest challenges for the future of AM. Norgaard et al. (2009) concluded 'adaptive management faces an inherent tension between its acknowledgment of complexity, uncertainty, and emergence and its presumption that goals and system metrics can be established to assess and adapt interventions'. Other approaches may be required to deal with uncertainty and complexity in the management of natural resources.

AM arouses both much enthusiasm and much scepticism but there is a need to foster more analytical dialogue. Specifically we have several suggestions to revive the further assessment and development of AM: firstly, to address issues of definition (we suggest refocusing on a formalized learning process and/or deliberate experimentation as the defining features of AM); secondly, to evaluate the value of this approach more systematically in a real world context in order to determine prospects for both learning and its expected value for management, thirdly to make such assessments in comparison to other approaches, particularly with respect to implementation costs. AM is not an end in itself, nor will it be useful in every context but rather it is a tool that offers the potential to improve management outcomes over time in some contexts. Explicit formalized analyses are needed in assessing in which situations an AM approach is appropriate for tackling uncertainty and complexity in environmental management.

\section{ACKNOWLEDGEMENTS}

We are grateful to Carol Colfer, Terry Sunderland, participants from the CIFOR Lower Mekong Conservation and Development Project workshop, Kai Lee, Jaboury Ghazoul, Sofia Wennberg-di Gasper and Jon Moen for discussions that contributed to the development of this study. Beate Mahl provided valuable help with data collection. We are also grateful to two anonymous reviewers whose comments improved the manuscript. Part of the research was funded through Future Forests, a multidisciplinary research programme supported by the Foundation for Strategic Environmental Research (MISTRA), the Swedish Forestry Industry, the Swedish University of Agricultural Sciences (SLU), Umeå University and the Forestry Research Institute of Sweden.

\section{References}

Allen, C.R., Fontaine, J.J., Pope, K.L. \& Garmestani, A.S. (2011) Adaptive management for a turbulent future. Fournal of Environmental Management 92: 1339-1345.

Allen, C.R. \& Gunderson, L.H. (2011) Pathology and failure in the design and implementation of adaptive management. Fournal of Environmental Management 92: 1379-1384.

Anderies, J.M., Walker, B.H. \& Kinzig, A.P. (2006) Fifteen weddings and a funeral: case studies and resilience-based management. Ecology and Society 11(1): 21.

Ascoli, D., Beghin, R., Ceccato, R., Gorlier, A., Lombardi, G., Lonati, M., Marzano, R., Bovi, G. \& Cavellero, A. (2009) Developing an adaptive management approach to prescribed burning: a long-term heathland conservation experiment in northwest Italy. International fournal of Wildland Fire 18: 727-735.

Baron, J.S., Gunderson, L., Allen, C.D., Fleishman, E., McKenzie, D.H., Meyerson, L.A., Oropeza, J. \& Stephenson, N. (2009) Options for national parks and reserves for adapting to climate change. Environmental Management 44: 1033-1042.

Benson, M.H. \& Garmestani, A.S. (2011) Embracing panarchy, building resilience and integrating adaptive management through a rebirth of the National Environmental Policy Act (2011). Fournal of Environmental Management 92: 1420-1427.

Blackstock, K.L. (2009) Between a rock and a hard place: incompatible objectives at the heart of river basin planning? Water Science Technology 59: 425-431.

Blackstock, K.L., Dunglinson, J., Dilley, R., Matthews, K., Futter, M. \& Marshall, K. (2009) Climate proofing Scottish river basin planning: a future challenge. Environmental Policy and Governance 19: $374-387$.

Bond, C.A. \& Loomis, J.B. (2009) Using numerical dynamic programming to compare passive and active learning in the adaptive management of nutrients in shallow lakes. Canadian Fournal of Agricultural Economics 57: 555-573.

Boyd, C.S. \& Svejcar, A.J. (2009) Managing complex problems in rangeland ecosystems. Rangeland Ecology and Management 62: 491-499. 
Brown, J.R. (2009) Climate change and ecology in rural lands. In: The Planners Guide to Natural Resource Conservation, ed. A.X. Esparza \& G. McPherson, pp. 39-56. Dordrecht, The Netherlands: Springer.

Bryan, B.A., Kandulu, J., Deere, D.A., White, M., Frizenschaf, J. \& Crossman, N.D. (2009) Adaptive management for mitigating Cryptosporidium risk in source water: a case study in an agricultural catchment in South Australia. Fournal of Environmental Management 90: 3122-3134.

Callicott, J.B., Crowder, L.B. \& Mumford, K. (1999) Current normative concepts in conservation. Conservation Biology 13: 2235 .

Canadian Forest Service (2011) Glossary of terms [www document]. URL http://cfs.nrcan.gc.ca/glossary/6/a

Castley, J.G., Hill, W., Pickering, C., Hadwen, W. \& Worboys, G. (2009) Developing ecological indicators of visitor use of protected areas: a new integrated framework from Australia. Sustainable Tourism Cooperative Research Centre Technical Report, STCRC Press, Australia.

CBD (2004) COP 7 Decision VII/11, Seventh Ordinary Meeting of the Conference of the Parties to the Convention on Biological Diversity, 9-20 February 2004. Kuala Lumpur, Malaysia [www document]. URL http://www.cbd.int/decision/cop/?id=7748

CMP (2007) Conservation Measures Partnerships Open Standards for the Practice of Conservation, Version 2.0. The Conservation Measures Partnership [www document]. URL http://www.conservationmeasures.org/wp-content/uploads/ 2010/04/CMP_Open_Standards_Version_2.0.pdf

Densmore, R.V. \& Karle, K.F. (2009) Flood effects on an Alaskan stream restoration project: the value of long-term monitoring. Fournal of the American Water Resources Association 45(6): 14241433.

Dzus, E., Grover, B., Dyer, S., Cheyne, D., Pope, D. \& Schieck, J. (2009) Setting, implementing and monitoring targets as a basis for adaptive management: a Canadian forestry case study. In: Setting Conservation Targets for Managed Forest Landscapes, ed. M.-A.Villard \& B.G. Jonsson, pp. 352-392. Cambridge, UK: Cambridge University Press.

Eberhard, R., Robinson, C.J., Waterhouse, J., Parslow, J., Hart, B., Grayson, R. \& Taylor, B. (2009) Adaptive management for water quality planning: from theory to practice. Marine and Freshwater Research 60: 1189-1195.

Feldman, D.L. (2008) Barriers to adaptive management: lessons from the Apalachicola-Chattahoochee-Flint Compact. Society and Natural Resources 21: 512-525.

Gregory, R., Ohlson, D. \& Arvai, J. (2006) Deconstructing adaptive management: criteria for applications to environmental management. Ecological Applications 16: 24112425.

Gosselin, F. (2009) Management on the basis of the best scientific data or integration of ecological research within management? Lessons learned from the Northern spotted owl saga on the connection between research and management in conservation biology. Biodiversity and Conservation 18: 777793.

Hauser, C.E. \& Possingham, H.P. (2008) Experimental or precautionary? Adaptive management over a range of time horizons. Fournal of Applied Ecology 45: 72-81.

Hilborn, R., Walters, C.J. \& Ludwig, D. (1995) Sustainable exploitation of renewable resources. Annual Reviem of Ecology and Systematics 26: 45-67.
Holling, C.S. (1978) Adaptive Environmental Assessment and Management. Chichester, UK: John Wiley and Sons.

Holling, C.S. (1996) Surprise for science, resilience for ecosystems, and incentives for people. Ecological Applications 6(3): 733-735.

Holling, C.S. \& Meffe, G.K. (1996) Command and control and the pathology of natural resource management. Conservation Biology 10: 328-337.

Jacobson, C., Hughey, K.F.D., Allen, W.J., Rixecker, S. \& Carter, R.W. (2009) Towards more reflexive use of adaptive management. Society and Natural Resources 22: 484-495.

Johnson, B.L. (1999) Introduction to the special feature: adaptive management: scientifically sound, socially challenged? Conservation Ecology 3: 10.

Johnson, F.A. (2011) Learning and adaptation in the management of waterfowl harvests. Fournal of Environmental Management 92: 1385-1394.

Kallis, G., Kiparsky, M. \& Norgaard, R. (2009) Collaborative governance and adaptive management: lessons from California's CALFED Water Program. Environmental Science and Policy 12: 631-643.

Karkkainen, B.C. (2003) Adaptive ecosystem management and regulatory penalty defaults: toward a bounded pragmatism. Minnesota Lam Reviem 97: 943-998.

Kay, R. \& Alder, J. (2005) Coastal Planning and Management. Second edition. Abingdon, UK: Taylor \& Francis.

Ladson, A.R. \& Argent, R.M. (2002) Adaptive management of environmental flows: lessons for the Murray-Darling basin from three large North American Rivers. Australian Fournal of Water Resources 5: 89-102.

Lawler, J.J. (2009) Climate change adaptation strategies for resource management and conservation planning. Annals of the Nem York Academy of Sciences 1162: 79-98.

Lee, K.N (1993) Compass and Gyroscope: Integrating Science and Politics for the Environment. Washington, DC, USA: Island Press.

Lee, K.N. (1999) Appraising adaptive management. Conservation Ecology 3(2): 3.

Levrel, H., Etienne, M., Kerbiriou, C., Le Page, C. \& Rouan, M. (2009) Co-modeling process, negotiations, and power relationships: some outputs from a MAB Project on the island of Ouessant. Society and Natural Resources 22(2): 172-188.

Linkov, I., Satterstrom, F., Kiker, G., Batchelor, C., Bridges, T. \& Ferguson, E. (2006) From comparative risk assessment to multi-criteria decision analysis and adaptive management: recent developments and applications. Environment International 32: 1072-1093.

Mackenzie, B.D.E. \& Keith, D.A. (2009) Adaptive management in practice: conservation of a threatened plant population. Management and Restoration 10(s1): S129-S135.

Martin, J., Runge, M.C., Nichols, J.D., Lubow, B.C. \& Kendall, W.L. (2009) Structured decision making as a conceptual framework to identify thresholds for conservation and management. Ecological Applications 19: 1079-1090.

Maxted, J.T., Diebel, M.W. \& Vander Zanden, M.J. (2009) Landscape planning for agricultural non-point source pollution reduction. II. Balancing watershed size, number of watersheds, and implementation effort. Environmental Management 43: 60 68.

McCarthy, M. \& Possingham, H. (2007) Active adaptive management for conservation. Conservation Biology 21: 956-963.

McFadden, J.E., Hiller, T.L. \& Tyre, A.J. (2011) Evaluating the efficacy of adaptive management approaches: is there a formula 
for success? Fournal of Environmental Management 92: 13541359.

McLain, R.J. \& Lee, R.G. (1996) Adaptive management: promises and pitfalls. Environmental Management 20: 437-448.

Melzer, R.I., Twyford, K.L., Rowston, C. \& Augusteyn, J.D. (2009) Pest arrest in Central Queensland: conserving biodiversity through pest management. Australian Fournal of Environmental Management 16: 227-235

Moir, W.H. \& Block, W.M. (2001) Adaptive management on public lands in the United States: commitment or rhetoric? Environmental Management 28: 141-148.

Moore, A.L. (2008) Managing populations in the face of uncertainty: adaptive management, partial observability and the dynamic value of information. Ph.D. thesis, Science, Mathematics and Statistics, The University of Melbourne, Melbourne, Australia.

Moore, C.T., Fonnesbeck, C.J., Shea, K., Lah, K.J., McKenzie, P.M., Ball, L.C., Runge, M.C. \& Alexander, H.M. (2011) An adaptive decision framework for the conservation of a threatened plant. Fournal of Fish and Wildlife Management 2(2):247-261.

Nature Conservancy (2007) Conservation action planning handbook: developing strategies, taking actions and measuring success at any scale. Nature Conservancy, Arlington, VA, USA [www document]. URL http://groups.ucanr.org/ HumboldtHabitatGoals/files/59025.pdf

Newlin, J.T. \& Johnson, P.A. (2009) Adaptive management of stream channel maintenance at bridge crossings in the Northern Tier Region, Pennsylvania. Journal of the American Water Resources Association 45(5): 1197-1208.

Nichols, J.D. (2000) Evolution of harvest management for North American waterfowl: selective pressures and pre-adaptations for adaptive harvest management. Transactions of the North American Wildlife and Natural Resources Conference 65: 65-77.

Norgaard, R.B., Kallis, G. \& Kiparskya, M. (2009) Collectively engaging complex socio-ecological systems: re-envisioning science, governance, and the California Delta. Environmental Science and Policy 12(6): 644-652.

Nyberg, J.B. (1998) Statistics and the practice of adaptive management. In: Statistical Methods for Adaptive Management Studies, ed. V. Sit \& B. Taylor, pp. 1-8. Victoria, British Columbia, Canada: British Columbia Ministry of Forests.

Ogden, A.E. \& Innes, J.L. (2009) Application of structured decision making to an assessment of climate change vulnerabilities and adaptation options for sustainable forest management. Ecology and Society 14(1): 11.

O'Toole, K., Wallis, A. \& Mitchell, B. (2009) Place based knowledge networks: the case of water management in south west Victoria, Australia. Water Alternatives 2(1): 101-114.

Owens, P.N. (2009) Adaptive management frameworks for natural resource management at the landscape scale: implications and applications for sediment resources. Fournal of Soils Sediments 9: 578-593.

Parma, A.M., Amarasekare, P., Mangel, M., Moore, J., Murdoch, W.W., Noonburg, E., Pascual, M.A., Possingham, H.P., Shea, K., Wilcox, C. \& Yu, D. (1998) What can adaptive management do for our fish, forests, food and biodiversity? Integrative Biology, Issues, Nems, and Reviems 1: 16-26.

Parr, C.L., Woinarski, J.C.Z. \& Pienaar, D.J. (2009) Cornerstones of biodiversity conservation? Comparing the management effectiveness of Kruger and Kakadu National Parks, two key savanna reserves. Biodiversity Conservation 18: 3643-3662.
Pierce-Colfer, C.J. (2005) The Complex Forest: Communities, Uncertainty, and Adaptive Collaborative Management. Washington, DC, USA: RFF Press.

Pereira, L.F.M., Barreto, S. \& Pittock, J. (2009) Participatory river basin management in the Sao Joao River, Brazil: a basis for climate change adaptation? Climate and Development 1: 1-8.

Pickett, S.T.A., Kolasa, J. \& Jones, C.G. (1994) Ecological Understanding London, UK: Academic Press.

Prato, T. (2009a) Evaluating and managing wildlife impacts of climate change under uncertainty. Ecological Modelling 220: 923930.

Prato, T. (2009b) Adaptive management of natural systems using fuzzy logic. Environmental Modelling and Software 24: 940944.

Prato, T. $(2009 c)$ Fuzzy adaptive management of social and ecological carrying capacities for protected areas. Fournal of Environmental Management 90: 2551-2557.

Priddel, D. \& Carlile, N. (2009) Key elements in achieving a successful recovery programme: a discussion illustrated by the Gould's Petrel case study. Ecological Management and Restoration 10: $\mathrm{S1}$.

Prober, S.M. \& Smith, P.F. (2009) Enhancing biodiversity persistence in intensively used agricultural landscapes: a synthesis of 30 years of research in the Western Australian wheatbelt. Agriculture, Ecosystems and Environment 132(3-4): 173-191.

Rogers, K. (1998) Managing science/management partnerships: a challenge of adaptive management. Conservation Ecology 2(2): R1.

Rogers, K., Roux, D. \& Biggs, H. (2000) Challenges for catchment management agencies: lessons from bureaucracies, business and resource management. Water $S A$ 26: 505-511.

Rout, T.M., Hauser, C.E. \& Possingham, H.P. (2009) Optimal adaptive management for the translocation of a threatened species. Ecological Applications 19: 515-26.

Ruhl, J. (2008) Adaptive management for natural resources: inevitable, impossible, or both? Rocky Mountain Mineral Law Institute Proceedings 54: 11-1.

Runge, M.C. (2011) Adaptive management for threatened and endangered species. Fournal of Fish and Wildlife Management 2: 220-233.

Sagoff, M. (2009) Environmental harm: political not biological. Fournal of Agricultural and Environmental Ethics 22: 81-88.

Salafsky, N., Margoluis, R. \& Redford, K. (2001) Adaptive Management: A Tool for Conservation Practitioners. Washington, DC, USA: Biodiversity Support Program.

Schreiber, S.G., Bearlin, A.R., Nicol, S.J. \& Todd, C.R. (2004) Adaptive management: a synthesis of current understanding and effective application. Ecological Management and Restoration 5(3): 177-182.

Seidl, R., Schelhaas, J.M., Lindner, M. \& Lexer, M.J. (2009) Modelling bark beetle disturbances in a large scale forest scenario model to assess climate change impacts and evaluate adaptive management strategies. Regional Environ Change 9: 101-119.

Simberloff, D. (2009) Moving beyond strawmen and artificial dichotomies: adaptive management when an endangered species uses an invasive one. Fournal of Agricultural and Environmental Ethics 22: 73-80.

Stankey, G.H, Clark, R.N. \& Bormann, B.T. (2005) Adaptive management of natural resources: theory, concepts, and management institutions. General Technical Report 
PNW-GTR-654, US Department of Agriculture, Forest Service, Pacific Northwest Research Station, USA.

Tompkins, E.L. \& Adger, W.N. (2004) Does adaptive management of natural resources enhance resilience to climate change? Ecology and Society 9(2): 10.

Tyre, A.J., Peterson, J.T., Converse, S.J., Bogich, T., Miller, D., Post van der Burg, M., Thomas, C., Thompson, R., Wood, J., Brewer, D.C. \& Runge, M.C. (2011) Adaptive management of bull trout populations in the Lemhi Basin. Journal of Fish and Wildlife Management 2: 262-281.

US Fish \& Wildlife Service (2011) Adaptive harvest management: 2011 hunting season. Report. US Department of Interior, Washington, DC, USA: 59 pp.

USEPA (2000) Lake Superior lakewide management plan [www document]. URL www.epa.gov/glnpo/lakesuperior/lamp2000

USEPA (2007) Gulf hypoxia action plan 2008: for reducing, mitigating, and controlling hypoxia in the Northern Gulf of Mexico and improving water quality in the Mississippi River Basin. US Environmental Protection Agency [www document]. URL http://www.epa.gov/owow/msbasin/taskforce/pdf/ 2008draft_actionplan.pdf

Varley, N. \& Boyce, M. (2006) Adaptive management for reintroductions: updating a wolf recovery model for Yellowstone National Park. Ecological Modelling 193: 315-339.

Walters, C.J. (1986) Adaptive Management of Renemable Resources New York, NY, USA: Macmillan.

Walters, C.J. (1997) Challenges in adaptive management of riparian and coastal ecosystems. Conservation Ecology 1: 21.
Walters, C.J. (2007) Is adaptive management helping to solve fisheries problems? Ambio 36: 304-307.

Walters, C.J. \& Hilborn, R. (1978) Ecological optimization and adaptive management. Annual Reviem of Ecology and Systematics 9: $157-188$.

Walters, C.J. \& Holling, C. (1990) Large-scale management experiments and learning by doing. Ecology 71: 2060-2068.

Wasserberg, G., Osnas, E.E., Rolley, R.E \& Samuel, M.D. (2009) Host culling as an adaptive management tool for chronic wasting disease in white-tailed deer: a modelling study. Fournal of Applied Ecology 46(2): 457-466.

Wilhere, G.F. (2002) Adaptive management in habitat conservation plans. Conservation Biology 16: 20-29.

Williams, B.K. (2011a) Passive and active adaptive management: approaches and an example. Fournal of Environmental Management 92: 1371-1378.

Williams, B.K. (2011b) Adaptive management of natural resources: framework and issues. Fournal of Environmental Management 92: 1346-1353.

Williams, B.K. \& Johnson, F.A. (1995) Adaptive management and the regulation of waterfowl harvests. Wildlife Society Bulletin 23: $430-436$.

Wilson, K., Carwardine, A.J. \& Possingham, H.P. (2009) Setting conservation priorities. Annals of the Nem York Academy of Sciences 1162: 237-264.

WWF (2007) Standards of conservation project and programme management. Report. WWF, Gland, Switzerland [www document]. URL www.panda.org/standards/complete 